\title{
'God kan net doen wat God wel doen': Petrus Abelardus se Megariaanse argument in Theologia 'Scholarium', Opera Theologica III
}

\begin{abstract}
Author:
Johann Beukes

Affiliation:

${ }^{1}$ Department of

Philosophy, University of

Johannesburg, South Africa

Correspondence to:

Johann Beukes

email:

jbeukes@uj.ac.za

Postal address:

PO Box 784849, Sandton

2146, South Africa

Dates:

Received: 01 June 2010

Accepted: 01 Sept. 2010

Published: 07 June 2011

How to cite this article: Beukes, J., 2011, “'God kan net doen wat God wel doen": Petrus Abelardus se Megariaanse argument in Theologia "Scholarium", Opera Theologica III', HTS Teologiese Studies/ Theological Studies 67(1), Art. \#883, 9 pages. DOI: $10.4102 /$ hts.v67i1.883
\end{abstract}

(C) 2011. The Authors. Licensee: OpenJournals Publishing. This work is licensed under the Creative Commons Attribution License.

\section{'God can only do what God does do': Peter Abelard's Megarian argument in Theologia 'Scholarium', Opera Theologica III}

Peter Abelard's contribution to a constellation of central themes in post-Carolingian medieval philosophy, namely on causation, necessity and contingency, with its discursive undertone of the relation between potentiality and actuality, is worked out in a rather informal way in one of his later works, Theologia 'Scholarium'. Typical of the fusion of philosophical questions and theological premises in medieval philosophy, Abelard addresses the issue by asking whether God can only do what God does. Abelard argues that God can do or not do or omit doing only those things which God does do or does not do or omits doing and that God can do or can not do or omit doing those things only in the way or at the time at which God does and not at any other. Given Abelard's fragmented and restricted access to the Aristotelian corpus regarding causality, how did he come to this Aristotelian-orientated conclusion? This article stresses the ancient quality of Abelard's argument from another angle, reminiscent of the so-called Master Argument of the Megarians, with specific reference to the dialectical legacy of Diodorus Cronus, according to whom what can be is what is: what is, in turn, is what must be. Actuality, for the Megarians, exhausts potentiality. The path of actuality cannot be undermined or compromised by issues of potentiality. God's actions are thus for both the Megarians and Abelard strictly determined and determining. God, in the end, can only do what God does. This article contributes to scholarship in medieval philosophy or theology by making this connection explicit and by thoroughly exploring the link between Abelard and his ancient predecessors.

\section{Inleiding}

Hierdie artikel word opgedra aan Prof. Dr Andries G. van Aarde, my voormalige promotor in die teologie, maar ook my lewensmentor, pastor en vriend. Ek dank God vir sy betekenisvolle en verrykende teenwoordigheid in my lewe, maar ook vir sy uiters toegewyde en bekwame diens oor meer as drie dekades heen in die akademie, sonderling juis daarby sy nederige diens in die kerk van Jesus Christus. Ek dank God vir jou, Andries.

Hierdie bydrae ${ }^{1}$ stel die vraag na Petrus Abelardus (1079-1142), naas Anselmus die invloedrykste Westerse filosoof in die post-Carolingiese periode, se bydrae tot een van die mees dominante

1.Die groter navorsingskonteks van hierdie publikasie kan met onderklemtoon dalk eerder in ' $n$ voetnota hanteer word. Hierdie artikel is naamlik die eerste in ' $n$ reeks oor onderbeklemtoonde tekste en temas in die Middeleeuse filosofie, gebed in ' $n$ navorsingsprojek wat reeds oor etlike jare strek, wat vanuit die 'donker eeue' as ' $n$ verset teen die verligtende pretensie van die moderne gelees kan word. Met hierdie projek word verdere momentum verleen aan die outeur se selfopgelegde taakstelling om die 'blywende erns van die monnik' in die eietydse filosofie/godsdiensfilosofie te rehabiliteer, om 'monnikearbeid' rakende die nosies van waarheid, skoonheid en geregtigheid in die filosofie/godsdiensfilosofie terug te bring (kyk Beukes 2005:1101-1103, 1124-1128). So word daar aansluiting gevind by' $n$ bepaalde variant van die postmoderne projek se aweregse rehabilitasie van vergete en verlore momente in die geskiedenis, met die oog op die voortgaande verwikkeling van ' $n$ risoom van Westerse herinnering, veral via die werke van Adorno, Heidegger en Foucault - en al die sonderlinge monnike van die Middeleeuse periode, vanaf Augustinus tot by Nicolaus. Die projek fokus wesenlik op 'n kreatiewe herlesing van onderbeklemtoonde primêre tekste en ondergekommentarieerde temas, sowel as netelige metodologiese kwessies, in die Middeleeuse filosofie. Martin Heidegger se beroemde opmerking (1958:37: 'Die wêreld word donker ... Die wesenlike kwessies, in dic gebeur di oo heugenis - die 20ste eeu - juis oor die verdonkering van die moderne (met ooglopende inbegrip van die bittere ironie dat die Verligting van die donker Middeleeue donkerder geword het as wat die 'donker eeue' ooit was of kon wees). Dit vra baie min om die prima facie geldigheid van hierdie premisse te rugsteun: sou die datums 1914-1919 en 1939-1945, om maar twee uit tallose tragiese 20ste eeuse merkers te verskaf, voorlopig genoegsaam wees? As die enigste manier om vorentoe toe te gaan, is om terug te bring wat ons verloor het, moet ons terugbring. Ons kan nie teruggaan nie - maar ons kan terugbring dít wat deur die moderne verontagsaam of selfs verdaag is, veral binne die konteks van die religie. Daarom word in hierdie projek gepoog om 'n vars oorsig en opgedateerde kontekstualisering van onderbeklemtoonde tekste en temas in die Middeleeuse navorsing te verskaf. Hierdie oorsig geskied via 'n herlesing van die primêre tekste as sodanig, om daarmee implisiet te argumenteer vir ' $n$ onapologetiese terugkeer na die bronne van die Westerse Self, waarvan religiositeit fundamenteel deel was (en is), voordat die Self in besit geneem is deur enersyds die moderne transendentalisering van die subjek en andersyds roekeloos opgelos is in wat die outeur herhaaldelik, in aansluiting by Michel Foucault se aweregs-historiese, provokatiewe moderniteitskritiek, beskryf het as die 'epistemologiese uitbranding van die postmoderne projek' (bv. Beukes 2005:1102, 2009a:3, 2009b:8). 
konstellasies van filosofiese temas in die Middeleeuse filosofie, naamlik kousaliteit, oftewel die verhouding tussen oorsaaklikheid en noodsaaklikheid, met die daaraan onderliggende diskursiewe ondertoon van die verhouding tussen aktualiteit en potensialiteit. Daar sal gepoog word om aan te dui hoe dit vir Abelardus moontlik was om 'n fundamentele bydrae tot hierdie oerfilosofiese diskoers te kon lewer, gegewe sy onvertroudheid met die Aristoteliese kousaliteitsleer, wat eers ruim na sy leeftyd die gestandaardiseerde invalshoek vir deelname aan hierdie debat in die latere Middeleeue geword het. Die artikel sal aandui dat daar by Abelardus 'n ander roete was: dat ons by Abelardus ' $n$ subtiele argumentatiewe aansluiting by die dialektiese determiniteitsleer van die antieke Megariërs vind.

Om op hierdie aanvanklike probleemstelling en aanduiding van ontknoping ietwat uit te brei: Abelardus, soos al sy postCarolingiese $^{2}$ tydgenote, het beperkte en gefragmenteerde toegang tot die beroemde Aristoteliese kousaliteitsleer gehad, gegewe sy lewensdatering in die onmiddellike nagloed van die Carolingiese Renaissance, waar skaars nog maar begin is met die rehabilitering van die klassieke Hellenistiese en Romeinse erfenisse, na die drie 'donker'3 eeue sedert die eerste Barbaarse inval in Rome in $410 \mathrm{nC}$. Dit sou trouens na Abelardus nog minstens een eeu duur voordat die erfenis van Aristoteles, via die Arabiese denkers Avicenna en Averroes, gerehabiliteer sou word van die Platoniesgedrewe onderdrukking van Aristoteliese premisses in die Westerse kerk van die post-Romeinse en Bisantynse periodes (Klibansky 1982:13ev). Tog voer Abelardus 'n Aristoteliaanse argument, of 'n argument wat baie aan Aristoteles herinner, aan die einde van sy minder bekende en laat bundel, losweg geredigeer as Theologia 'Scholarium', in Opera Theologica III, gevoed deur dit wat hy op geen ander plek kon vind nie as

2. Hoewel ' $n$ gestandaardiseerde periodisering van Middeleeuse filosofie altyd in dispuut sal wees, behoort daar met ses duidelik onderskeie institusiehistoriese periodes in hierdie millenniumlange epog gewerk te word. Die outeur se voorste vir ' $n$ historiese skema sien as volg daaruit:

1. Die vroeë of post-Romeinse periode (4de-7de eeue [410 \{Alaricus I\} - 663 \{Konstantyn II\}], met Augustinus [354-430] en Boethius [480-524] as die belangrikste filosofiese eksponente).

2. Die Carolingiese periode (8ste-9de eeue [742 \{†Karel I\} - $840\{$ \{Louis I\}], met Alcuin van York [730-804] en Johannes Scotus Eriugena [815-877] as die belangrikste filosofiese geleiers van die Carolingiese Renaissance).

3. Die post-Carolingiese periode (10de-12de eeue [877 \{†JohSE\}-1095 \{aanvang van die kruistogte\}, met Anselmus [1033-1109] en Abelardus [1079-1142] as die mees gevolgryke onder die filosowe wat sou baat by die sporadiese rehabilitering van die antieke in die Carolingiese Renaissance)

4. Die vroeë universiteitsperiode (12de - 13de eeue [1088 \{stigting van die Universiteit van Bologne, die eerste Europese universiteit\} - 1225 \{geboorte van Thomas Aquinas\}, en die opkoms van die 12 de eeuse filosofiese skole]).

5. Die skolastiese periode (13de-14de eeue [1225, geboorte van \{Aquinas\}-1348 Die skolastiese periode (13de-14de eeue $[1225$, geboorte van $\{$ Aquinas $\}-1348$
\{†Willem van Ockham\}, met Thomas Aquinas, Hendrik van Gent, Johannes \{ Willem van Ockham\}, met Thomas Aquinas, Hendrik van Gent, Johannes
Duns Scotus, Sigerius van Brabant en Willem van Ockham as die beroemdstes Duns Scotus, Sigerius van
onder die hoë skolastici]).

6. Die laat-skolastiese periode (15de-16de eeue [401, geboorte van Nicolaus van Kusa, die laaste Middeleeuse of eerste 'moderne' filosoof\} - 1517 \{Martin Luther en die Wes-Europese Kerkhervorming\}]).

7. Abelardus word dus hier, hoewel met' $n$ laat datering vir ' $n 12$ de eeuse filosoof tematies as ' $n$ post-Carolingiese filosoof binne die konteks van die Carolingiese Renaissance hanteer en nie soseer as ' $n$ pertinente voorloper van die Italiaanse Renaissance en die opkomende universiteitswese in Wes-Europa nie.

3.Die begrip 'donker', ongetwyfeld die mees pejoratiewe begrip waarmee die vroee Middeleeue in die modernistiese geskiedsbegrip met kenmerkende vooroordeel 'verlig' is, word hier polemies aangebied. Die moderne interpretasie van die Middeleeue, meegevoer deur die opvattinge van 'n teleologiese historisme, ' $n$ onderwerpende, instrumentele rasionaliteit, sowel as ' $n$ transendentale subjektiwiteit en die nuutgevonde romantiese Self van die $18 \mathrm{de}$ eeu, het in die resepsiegeskiedenis ' $n$ karikatuur van die Middeleeue as barbaars, onverlig, onkundig en wreed opgestel en baie effektief geperpetueer. Die elitisme van hierdie onkundig en wreed opgestel en baie effektief geperpetueer. Die elitisme van hierdie Rousseaanse, later Kantiaanse en uiteindelik Rankeaanse geskiedsbegrip
blywende teiken in die eietydse kritiek van die moderne gevestig word. in die leer van die antieke Megariaanse konteks. Hy vestig hom met hierdie argument as 'n mede-wegbereider vir die volle rehabilitering van Aristoteles in die vroeë skolastiek van die laat 12 de eeu en veral die hoë skolastiek van die 13de en 14de eeue, histories parallel met die toenemende stroom van Latynse vertalings van die Arabiese ${ }^{4}$ vertalings van en kommentare op die Griekse tekste. Abelardus se bydrae tot die Westerse register, spesifiek as kommentator en interpreteerder van die antieke tradisie(s), juis in die afwesigheid van 'n werkbare Aristoteliese korpus, kan trouens moeilik oorskat word ${ }^{5}$.

Die filosofies-teologiese konteks en tweesnydende vraagstelling waarbinne hierdie argument deur Abelardus gevoer word, is spesifiek in die laat 11de eeu (Luscombe 1969:45-61), met die eerste kruistogte wat 'n aanvang neem en beslissend in die veronderstelde heilsgeskiedenis verantwoord moet word, krities belangrik: Wat kan God (nie) doen (nie)? Voordat Abelardus se hantering van hierdie vraag ondersoek word, is dit nodig om die gangbare kousaliteitsleer in die Middeleeue sowel as die sogenaamde Meesterargument van die antieke Megariërs te kontekstualiseer.

\section{Die gangbare kousaliteitsleer in die Middeleeue}

Vroeëre sowel as latere Middeleeuse denkers het feitlik sonder uitsondering die diep gevestigde opvatting onder antieke filosowe, naamlik dat 'n verstaan van die werklikheid geformuleer en gesistematiseer kan word aan die hand van die konsepte oorsaaklikheid en noodsaaklikheid, oorgeneem en gehandhaaf. Dit beteken: Daar is geen gebeure sonder 'n oorsaak nie. Niks is nie veroorsaak nie. Oorsaaklikheid word geag om in hierdie sin die diepste grond van die werklikheid te wees. Verder is 'n oorsaak nie bloot nóg 'n gebeure wat die gevolg daarvan voorafgaan of bykans gelyktydig daarmee geskied nie: Elke gebeure het 'n oorsaak wat presies net daardie gebeure veroorsaak het; die gebeure of gevolg volg dus vanuit die oorsaak op grond van 'n intrinsieke noodsaaklikheid. Daar is, anders gesê, 'n gedetermineerde verhouding tussen oorsaaklikheid en noodsaaklikheid. Dit is wat met 'kousaliteit' in die gangbare Middeleeuse sin van die woord bedoel word.

Kousaliteit, as die rigiede verhouding tussen oorsaaklikheid en noodsaaklikheid, was inderdaad 'n sentrale en selfs dominante tema in die Middeleeuse filosofie. Die rede daarvoor is dat die post-Carolingiese filosofie die geskepte

4. Hoewel ' $n$ ietwat triviale opmerking, is dit nodig om te beklemtoon dat die beskikbaarstelling van die Hellenistiese erfenis, veral met betrekking tot die Aristoteliese tekste, nie gedurende die Carolingiese Renaissance in Latyn ondervang is nie, maar dat dit via die beroemde Arabiese skole en figure soos Avicenna en Averroes vanaf die laat 9de eeu in Arabies na die Westerse filosowe van die $10 \mathrm{de}$ eeu en later deurgesypel het. Latynse vertalings van die Griekse tekste was dus aanvanklik gebaseer op die Arabiese vertalings van die Griekste tekste. Die rehabilitasie van Aristoteles in die latere Middeleeue en Italiaanse Renaissance is volledig toe te skryf aan die vertalings en kommentare van figure seos Avicenna is volledig toe te skyf aan die vertalings en ko hicenna en Averroes (vir ' $n$ uitgebreide bespreking van hierdie belangrike resepsiekwessie, kyk
Copleston [1972:104-124]; kyk ook Armstrong [1967:iv]).

5.Kyk Brower \& Guilfoy (2004), Clanchy (1999:80-85), Wilks (2008), Wadell (2008), Sweeney (2006), Luscombe (1992:127-138), Mews (2001) en Mews \& Jolivet (1990:135-140) vir relatief resente waarderings. 
of veroorsaakte werklikheid toenemend as 'n rasionele manifestasie van God self beskou het en dat die rasionele ondersoek na hierdie veroorsaking of oorsaaklikheid die weg na God self sou aandui. Die filosofies-teologiese temas waarmee denkers hulle tussen die 10de en 14de eeue besig gehou het, het daarom almal kousaliteit as 'n sentrale element: Die eerste oorsaak of Beweger (Aristoteliese taal vir God), die vraag na die ewigheid van die wêreld self, die verhouding tussen die voorsienigheid van God en natuurlike of oënskynlik spontane prosesse, die rol van die vrye wil in die etiek, die sonde- en verlossingsleer, die verhouding tussen vrye wil en determinisme, die verhouding tussen identiteit en onderskeid, die verhouding tussen die universele en die partikuliere, en so meer. Hierdie temas vooronderstel almal ' $n$ bepaalde posisionering ten opsigte van die kousaliteitsleer.

In die latere Middeleeue was hierdie posisionering konsekwent Aristotelies van aard: Latere Middeleeuse denkers (d.w.s. in die hoë en laat skolastiek), het met die gelatiniseerde beskikbaarstelling van die Aristoteliese korpus vanaf die laat 12 de eeu, Aristoteles se kousaliteitsleer oorgeneem en onverkort gehandhaaf. Hiervolgens (Aristoteles 1984:1101-2; kyk Alexander 1899:23ev) is daar vier soorte oorsake: Materiële oorsake, verrigtingsoorsake, formele oorsake en finale oorsake. Materiële oorsake het te make met ' $n$ verstaan van die materiaal of substansie van 'n saak, waaruit 'n saak bestaan. Verrigtingsoorsake het te make met ' $n$ verstaan van die werksverrigting van kousaliteit, hoe 'n saak tot stand gekom het tot die saak wat tans bestaan. Formele oorsake het te make met 'n verstaan van die diepste essensie van 'n saak, wat 'n saak in werklikheid is (in ooreenstemming met die Aristoteliese vormleer, wat fokus op die struktuur en interne organisering van 'n saak, anders as die Platoniese Vorme, wat 'n metafisiese konsep is). Finale oorsake het te make met die telos, doel of uiteinde van die saak, hoe die veroorsaakte saak in die veroorsaakte staat aangewend kan word. Om kortliks te illustreer: Indien 'n Aristoteliese kousaliteitsverduideliking aangewend word om die veroorsaakte saak 'tafel' te verduidelik, sou hout die materiële oorsaak wees, die skrynwerker sou die verrigtingsoorsaak wees, die pote, blad en skroewe sou die formele oorsaak wees en die uiteindelike aanwending van die saak - aansit aan tafel - sou die finale oorsaak wees.

Latere Middeleeuse denkers het ook die Aristoteliese leer rondom relasionele noodsaaklikheid oorgeneem: Hiervolgens is noodsaaklikheid 'n begrip wat in terme van die verhouding tussen oorsaak en gevolg verstaan moet word (Aristoteles 1984:1103-1105). In Aristoteles se kousaliteitsleer kristalliseer dit uit in relatiewe en hipotetiese noodsaaklikheid. Relatiewe of betreklike noodsaaklikheid bestaan wanneer 'n veroorsaakte saak relatief noodsaaklik tot die oorsaak daarvan bestaan, met ander woorde, die saak kon slegs deur die een betrokke veroorsakende saak veroorsaak word. Hipotetiese noodsaaklikheid bestaan wanneer met 'n verantwoorde of rasionele aanname aangaande die noodsaaklikheid gewerk word, gegrond op waarneembare materiële prosesse: Byvoorbeeld, dat dit noodsaaklik is dat alle lewende wesens gevoed moet word, of andersins noodsaaklikerwys sal sterf. Latere Middeleeuse denkers het die Aristoteliese standpunt gehandhaaf dat sowel gevolge as oorsake noodsaaklik is in beide die relatiewe en hipotetiese sin: 'n Gevolg is relatief noodsaaklik tot die oorsaak daarvan, en 'n oorsaak is hipoteties noodsaaklik vir die gevolg daarvan.

Die handhawing van die vier oorsake en die opvatting van relasionele noodsaaklikheid dui dan op 'n streng determinisme in Aristoteles se kousaliteitsleer: Gegewe 'n oorsaak, kan een en slegs een gevolg daaruit voortkom; gegewe 'n gevolg, kan een en slegs een agent die oorsaak daarvan wees. Dit laat geen intervensie deur kans, toeval en spontaniteit toe nie. Hierdie streng determinisme loop soos 'n goue draad deur die Middeleeuse filosofie, maar nie sonder hewige problematiserings nie. Streng determinisme het verreikende konsekwensies vir 'n verstaan van enersyds God en die wêreld en die sosiaal-etiese werklikheid andersyds.

Wat God en die wêreld betref, ontstaan die vraag of God, of in Avicenna se streng Aristoteliese begrippeskat, 'die eerste oorsaak', 'n ander of verskillende eerste gevolg kon veroorsaak. Binne die Middeleeuse konteks word sonder meer aanvaar dat God noodsaaklik is vir die wêreld. Is die wêreld dan ook relatief noodsaaklik tot God as eerste oorsaak? Sou God steeds God wees indien God die wêreld nie veroorsaak het nie, of 'n ander wêreld veroorsaak het? Indien die wêreld noodsaaklik veroorsaak is deur die eerste oorsaak, wat is die rol van kans, spontaniteit en vryheid in hierdie rigied veroorsaakte maar noodsaaklike bestel? Andersom: Indien die wêreld begin het as die realisering van een uit baie moontlikhede (gegewe die besliste Middeleeuskerklike opvatting dat God se almag op geen wyse beperk mag word nie, ook nie om 'n oneindige hoeveelheid alternatiewe wêrelde te veroorsaak nie), hoe moet God se potensialiteit om meer as een gevolg te veroorsaak, om alternatiewe gevolge te veroorsaak, binne die konteks van streng determinisme hanteer word?

Wat die sosiaal-etiese werklikheid betref, hou streng determinisme ernstige implikasies in, wat veral in die laaste fase van die skolastiek geproblematiseer is deur denkers soos Johannes Duns Scotus en Willem van Ockham: Indien enige menslike handeling relatief noodsaaklik is tot ' $n$ hele reeks van oorsake en gevolge (synde self 'n gevolg van 'n oorsaak), 'n reeks wat by die begin en die eerste beweger begin het, kan daar nog van verantwoordelike etiese agente gepraat word, soos wat Aristoteles ongetwyfeld in terme van phronesis sou benadruk?

Van hierdie probleme weet die 12de eeuse Abelardus baie min, omdat hy van Aristoteles werklik min weet (Clanchy 1999:96; kyk Lewis 1987:89). Hy ken nie die streng Aristoteliese determinisme wat vanaf Avicenna en die Arabiese wêreld die Europese wêreld hoofsaaklik via Spanje sou binnesypel nie. Hy het feitlik geen toegang tot Aristoteles se uitgewerkte kousaliteitsleer nie (Clanchy 1999:96; ook Lewis 1987:9193). Hy kan nie soos sy hoë-skolastiese opvolgers in Parys 
problematiserend daarop reageer nie. Wat hy wel het, is identies dieselfde Middeleeuse vrae: Wat het alles begin? Kon iets anders dit begin het? Het dit toevallig begin? Indien daar 'n eerste oorsaak was, was daar net een moontlike gevolg? Was dit God? Wat kan God doen? Wat kan God nie doen nie? Wat dus, is die filosofies-teologiese verhouding tussen aktualiteit en potensialiteit?

Abelardus moet dieselfde vrae beantwoord as sy latere vennote, maar sonder die volledige Aristoteliese korpus, veral sonder die fyn genuanseerde kousaliteitsleer wat later soveel eerbied in die hoë skolastiek sou afdwing (kyk ook Luscombe 1992:128; Wilks 2008:85-90). Al wat Abelardus as 'n post-Carolingiaan wel het, is vonke van 'n ouer rasionaliteit, fragmente van die antieke Megariese geestesgoed.

\section{Die Megariaanse Meesterargument}

Voordat Diodorus Cronus se Meesterargument met die oog op Abelardus se terugkoppeling na hierdie argument gekontekstualiseer en uiteengesit kan word, moet die agtergrond van hierdie konneksie eers verantwoord word.

Die talle kontemporêre monografieë ${ }^{6}$ wat oor Abelardus beskikbaar is, beklemtoon sy bekende bydraes in logika, etiek, metafisika en teologie via sy nominalistiese en dialektiese posisies en fokus met weinig uitsondering op Abelardus se beroemde tekste in hierdie deeldissiplines. Abelardus se bekendste tekste val in drie afdelings uiteen:

- sy dialektiek (insluitende logika, taalfilosofie en metafisika), opgeneem in sy twee beroemdste werke Logica 'Ingredientibus' en Dialectica', met die vier kleiner werke in logika daaronder gegroepeer, naamlik Introductiones parvulorum, Logica nostrorum petitioni sociorum, Tractatus de intellectibus en Sententiae secundum Magistrum Petrum

- sy etiek, opgeneem in Ethica seu Scito teipsum en sy kontroversiële dialoog tussen 'n Jood en Christen, Collationes (later gesirkuleer as Dialogus inter Philosophum, Iudaeum et Christianum

- sy filosofiese teologie, opgeneem in Theologia 'Summi Boni', Theologia Christiana en die laat Theologia 'Scholarium'.

Hierdie laaste drie werke is in die resepsiegeskiedenis berug omdat elkeen talle keer herskryf is in Abelardus se pogings om sy gedagtes meer ortodoks in te kleur, in aanvaarbare

6.Dit spreek vanself dat die Abelardus-navorsing en die sekondêre literatuur wat oo meer as 700 jaar strek, onoorsigtelik geword het. Vir die momentare, geannoteerde vertalings van primêre tekste en monografiese werke in die Abelardus-navorsing, kyk Mews (2001), Spade (1995), Clanchy (1999), Marenbon (1999), Brower \& Guilfoy (2004 ['n uitstekende bloemlesing]) en Wadell (2008). Di ouer 20ste eeuse werke wat status geniet as standaardverwysings in die Abelardus literatuur, is McCabe (1972 [1901]), Dahmen (1906), Murray (1967), Luscombe (1969, 1971, 1992), Weingart (1970) en Tweedale (1976)

7.Die datering van Abelardus se tekste is al vir baie eeue ' $n$ kontroversiële kwessie in die navorsing, omdat Abelardus tot en met sy dood sy eie werk pal geherredigee en gedeeltes selfs volledig herskryf het, wat daartoe gelei het dat verskeie en verskillende edisies van ' $n$ bepaalde werk in omloop was en steeds is (Mews 1986:75; kyk McCabe 1972:54). Dit geld ook vir die teks Theologica 'Scholarium', wat in hierdie artikel aan die orde gebring word. Hoewel dit duidelik ' $n$ laat teks is omdat daar verwysings na voorafgaande tekste is wat feitlik die hele oeuvre insluit, is die datum van eerste publiekstelling (uiteraard nie publikasie oeuvre insluit, is die datum van eerste publiekstelling (uiteraard nie publikasie in die modern navorsingsin nie) onbekend. Die teks wek ook die indruk van eerder' $n$ sameflansing van filosofies-teologiese temas wat vinnig in die eerste groepering van 12de eeuse soos in die sistematiese werke Dialectica en Logica 'ingredientibus' reflekteer (kyk Mews 1986:81). kerklike terminologie te herformuleer en sy posisie in die legendariese skermutseling met Bernardus van Clairveaux rakende die talle aanklagte teen die beweerde ketterse kwaliteit van sy nominalisme te bestendig.

Maar met 'Scholarium' is dit nog meer problematies as met die twee ouer werke, 'Summi Boni' en Christiana. 'Scholarium' word in die navorsing as een van Abelardus se mees obskure tekste gereken: Eerstens is die teks waarskynlik postuum geredigeer en gebundel, afgesien dat die subtekste wat daarin opgeneem is, deur Abelardus self telkens herskryf is. Tweedens is die teks, naas die daargestelde standaardhandboek Sententiae secundum Magistrum Petrum, die enigste van Abelardus se tekste wat gebundel is met die uitsluitlike doel om in die opkomende filosofieskole van die 12 de eeu as handleiding en studiemateriaal gebruik te word, soos wat die redakteurstitel in aanhalingstekens, 'Scholarium', pertinent aandui. Derdens: Wanneer die uitgawe van Buytaert en Mews (Abelardus 1987) ter hand geneem word, is dit duidelik vanuit die Latynse teks self dat die teks argumentatief minder formeel en gestruktureerd aandoen as die voorafgaande tekste, hoewel dit ortografies nie anders vertoon as 'n filosofieteks uit dieselfde periode nie, veral met verwysing na die menigte voetnotas, grammatikale kommentaar, kruisverwysings en eksplisiete debat in voetnotas met voorgangers. Dit is wel die narratiewe soepelheid en nie-rigiede kwaliteit van die teks wat dit differensieer van Abelardus se vroeëre werke en ander filosofietekste uit dieselfe periode. Die teks is stilisties duidelik anders as Abelardus se vroeëre tekste. Daarom moet dit nie as vreemd beskou word dat die teks buite die Latyngeletterde omgewing onbekend en inderdaad onbemind is nie. Die teks is ook ondergekommentarieerd, gegewe die oorvloed vertalings van en kommentaar op Abelardus se vroeëre tekste, veral Logica 'Ingredientibus' en Dialectica, in die resepsiegeskiedenis (Lewis 1987:90).

Verrassend het 'n hoogs gerespekteerde frontnavorser in Middeleeuse filosofie, Martin Tweedale, egter nie ekserpe vanuit Logica 'Ingredientibus' en Dialectica nie, maar ekserpe vanuit 'Scholarium' in die2004-uitgawevan diegevierdeBosley \& Tweedale bloemlesing, Basic issues in medieval philosophy, vanuit die Latyn vertaal, kursories gekommentarieer en in die bloemlesing opgeneem (Tweedale 2004:19ev). Daarmee is die teks uit betreklike vergetelheid ontruk en is die Abelardus- en groter 12de eeuse navorsing in staat gestel om die teks vir die eerste keer in ' $n$ baie lang tyd naas die meer beroemde Abelardus- en ander filosofietekste uit die 12de eeu te lees (kyk ook Luscombe 1992:129; Colish 1968:14ev). Dit is juis 'n bondige opmerking wat Tweedale in sy kommentaar op 'Scholarium' gemaak het, saamgelees met 'n paar ander kursoriese opmerkings wat hy reeds twee dekades vroeër oor Abelardus en die 'kulminasie van 'n ou logika' gemaak het (Tweedale 1982:143-157), wat die belangrikste prikkels vir die onderhawige navorsing was: 'Abelard attributes to God a position held by some ancient philosophers (the

8.Vir kritiese rekenskap van die problematiese redaksie- en resepsiegeskiedenis van hierdie primêre tekste, kyk veral Mews (1986:73v); kyk ook Clanchy (1999:21ev), Luscombe (1967:19ev), Marenbon (1999:25ev) en McCabe (1972:14). 
Megarians), according to whom what can be is what is ...' (Tweedale 2004:19). Buiten Tweedale se bondige opmerking, wys die meer onlangse navorsing ${ }^{9}$ hierdie konneksie, tussen Abelardus en die Megariërs, nie implisiet uit nie en ontgin dit ook nie eksplisiet by wyse van grondige ekskurs nie. Hierdie konneksie mag in die voor-20ste eeuse navorsing 'n oorweging gewees het of selfs behoorlik uitgewerk gewees het: Gegewe die punteneurigheid en presisie van die skolastiese styl, is dit selfs waarskynlik. Maar die konneksie het in die moderne navorsing verlore gegaan en moet (weer) verhelder word.

Tweedale se uitspraak verdien dus opnuut aandag in die navorsing. Abelardus het wel nie toegang tot Aristoteles se oeuvre gehad nie, pertinent nie ten opsigte van Aristoteles se kousaliteitsleer nie (hoewel Westerse monnike beperkte toegang tot minstens dele van Aristoteles se proposisionele logika vanaf die 10de eeu gehad het), maar het tog 'n Aristoteliese posisie gehandhaaf, lank voordat dit die gangbare diskursiewe terugkoppeling in die skolastiek sou word. Dit is daarom betekenisvol om vas te stel watter antieke filosofiebronne wel vir Abelardus toeganklik was. Op die minste verskaf 'n perspektief hierop 'n moontlike en selfs geldige verklaring vir Abelardus se aweregse posisie in die kousaliteitsdebat van die vroeë Middeleeue ${ }^{10}$.

Die begrip 'Megariërs' dien in hierdie artikel as 'n versamelnaam vir 'n groep vroeg-Hellenistiese filosowe wat in die historiese ensiklopedie van die Westerse filosofie tematies saamgebind word op grond van hulle assosiasie met die Sokratiese denker Eubulides van Miletus (circa 400 vC), 'n tydgenoot en opponent van Aristoteles en die vernaamste opvolger van Euklides van Megara (435-365 vC), die stigter van die sogenaamde Megariese ${ }^{11}$ skool (later meerendeels, hoewel met onderskeie vertakkinge, ook bekend as die Dialektiese skool). Filo en Diodorus Cronus staan bekend as die twee Megariërs wat Euklides en Eubulides se werksaamhede in proposisionele logika, paradoksteorieë en dialektiek op gevolgryke wyse gesistematiseer het en aansienlik ontwikkel het (Sedley 1977:77-80; kyk Prior 1955:206). Dit was egter Diodorus Cronus wat met 'n ontwikkeling van die dialektiese determiniteitsleer wat hy van sy Megariese voorgangers ontvang het, 'n bydrae gemaak het tot die kousaliteitsdebat wat vir eeue daarna, inderdaad tot diep in die Middeleeue, weerklank sou vind.

9.Kyk Spade (1995), Clanchy (1999), Luscombe (1992), Mews (2001), Sweeney (2006), Marenbon (1999), Brower \& Guilfoy (2004) en Wadell (2008). Hierdie artikel werk Marenbon (1999), Brower \& Guilfoy (2004) en Wadell (2008). Hie.

10.Die groot uitdaging én probleem in die Middeleeuse filosofie, naamlik die massiewe kommentaar- en resepsietradisie op enige Middeleeuse teks, selfs betreklik obskure tekste soos 'Scholarium', oor 'n periode van minstens 1100 jaar (indien die post-Carolingiese filosofie as ' $n$ reeds laat ensiklopediese merke gebruik sou word), moet die navorsing nie ontmoedig om telkens die ou tekste te kommentarieer nie. Sonder hierdie produktiewe bereidwilligheid tot 'diskoers' sou Middeleeuse filosofie inderdaad ' $n$ steriele filosofies-historiese subdissipline wees en nie die vermoë kon voorbehou om die krities-rehabiliterende informant van die postmoderne te wees, soos betoog in Beukes (2005) nie.

11.Vir gesaghebbende inleidings en oriëntasies ten opsigte van die ontstaan en ontwikkeling van die Megariese skool, kyk Bobzien (1993:124-130, 1998:97-111), Sedley (1977:74-80), Prior (1955:205-213) en Weidemann (1987:18-25). Let ook daarop dat die verhouding tussen die Megariese en Dialektiese skool self n sensitiewe kwessie is: talle navorsers is van mening dat dit een en dieselfde skool was en dat die dialektici geen vernuwende bydrae gelewer het tot die oorgeneemde uitsette van die Megariese skool op daardie stadium nie.
Met hierdie sogenaamde Meesterargument, ho kurieuôn logos, het Diodorus die oogmerk om op logiese gronde te argumenteer dat slegs die werklikheid moontlik is. Slegs die geaktualiseerde het potensiaal.

Diodorus se definisie van wat moontlik is, word deur middel van twee duidelike aansprake begrond: Eerstens, dat alles wat werklik is of werklik sal wees, moontlik is; tweedens, dat alles wat moontlik is, werklik is of werklik sal wees. Die eerste aanspraak is nie deur Hellenistiese filosowe bevraagteken nie ${ }^{12}$. Dit is die tweede aanspraak wat duidelik kontra-intuitief is en wat deur logiese argument gestaaf sou moes word. Dit is juis hierdie tweede aanspraak wat Diodorus met sy Meesterargument wil begrond (Weidemann 1987:32-41, 2008:131-133).

'n Begaafde spesialisnavorser in vroeg-Middeleeuse filosofie, Suzanne Bobzien wys daarop dat die argument self in die antieke en vroeg-Middeleeuse periodes behoue gebly het, maar gedurende die latere Middeleeuse periode, waarskynlik vanweë die volle rehabilitering van Aristoteles se kousaliteitsleer, in die slag gebly het: 'The [full] argument has not come down to us; all we have is a brief passage'(2004:5). Bobzien (2004:5; kyk Weidemann 1987:50 53) gebruik ${ }^{13}$ Epiktetus se kommentaar op hierdie passasie om die argument self te verwoord: Die Meesterargument is vanuit die vertrekpunt ontwikkel dat daar 'n algemene konflik tussen die volgende drie stellings (I-III) is, wat in IV ontknoop kan word.

I. Elke reeds-gerealiseerde $\mathrm{e}^{14}$ proposisie is noodsaaklik waar.

II. 'n Onmoontlike proposisie kan nie vanuit 'n moontlike proposisie voortkom nie.

III. ' $\mathrm{n}$ Proposisie is moontlik wanneer dit nie reeds waar is of noodsaaklik waar sal wees nie.

IV. Diodorus, bewus van die kontradiksie wat die

12 Alexander van Afrodisië (1899:183-186), Denyer (1981:35), Lewis (1987:82), kyk Bobzien (2004:5)

13.Die rekonstrusie van die Meesterargument roep drie voorwaardes op, (1) I en II soos oorgelewer deur Epiktetus, moet gehandhaaf word, (2) die rekonstruksie moet voldoen aan logiese en konseptuele vereistes soos wat dit in die antieke periode beskikbaar was en (3) dit moet, in terme van die antieke eis vir filosofiese redevoering, moontlik wees om die argument in eenvoudige omgangstaal te verwoord, wat sowel tegnies korrek is as wat dit by 'n openbare debat toeganklik sou moes wees.

14.Prior ([1955:208]; kyk Mates [1949:236]; Denyer [1981:33]; Mates [1949:236]) wys daarop dat die Griekse woord vir 'verlede' (parelêluthos) 'n gestandaardiseerde Stoïsynse konsep vir proposisies in die verlede tyd was - nie omdat die proposisie in die verlede tyd gestel is nie, maar omdat die proposisie oor ' $n$ saak in die verlede handel. Dit is hiervolgens algemeen aanvaar dat alle waar proposisies wat oor' $n$ saak in die verlede handel, nie ' $n$ verandering in waarheidswaarde kan ondergaan nie en daarom noodsaaklik waar is. Die betrokke war proposisie wat oor' $n$ saa nie en daarom noodsaaklik waar is. Die betrokke waar proposisie wat oor ' $\mathrm{n}$ saak In die verlede handel, sluit dus nie alle proposisies oor die verlede in nie, maa sluit ' $\mathrm{n}$ toestand of gebeure in die verlede in. Die proposisie 'Ek het na Athene toe gegaan' korrespondeer met die gebeure dat ek wel na Athene toe gegaan het en dat my toestand een van 'in-Athene' was. Dit kan nooit vals wees dat ek na Athene toe gegaan het nie. Veronderstel ek het verlede maand Athene toe gegaan: Dan sal dit ook more waar wees dat ek na Athene toe gegaan het; dit sal 'n toekomstige waar noodsaaklikheid wees. Die waarheid van die proposisie is natuurlik volledig gegrond in die saak dat ek inderdaad wel Athene toe gegaan het en dat dit nooit waar kan wees dat ek nie na Athene toe gegaan het nie. Duidelikheidshalwe sou die proposisie selfs nog sterker geformuleer kon word: 'Die saak is dat ek na Athene toe gegaan het'. Maar aan die ander kant: Die proposisie 'Jy het nie na Athene toe gegaan nie' korrespondeer nie met ' $n$ toestand of gebeure in die verlede tyd nie. Veronderstel jy het tot nou toe nog nooit na Athene toe gegaan nie: dan is daardie proposisie huidig waar. Maar indien jy volgende week Athene toe sou gaan, is die proposisie 'Jy het nie na Athene toe gegaan nie' nie meer waar nie. Daarom is proposisie Jy het nie na Athene toe gegaan nie nie meer waar nie. Daarom is die proposisie huidig waar, maar nie noodsaaklik nie. Die proposisie kan nie soos die eersgenoemde duidelikheidshalwe geformuleer word 'Die saak is dat jy nie Athene toe gegaan het nie': Want daar was nooit so ' $n$ saak nie. Daarom is Prio ( A re re waar proposisie wat korrespondeer met ' $n$ toestand of gebeure in die verlede tyd is noodsaaklik'. 
verhoudinge tussen I-III oproep, gebruik I en II om te postuleer: Niks is moontlik wat nie waar is of noodsaaklik waar sal wees nie ${ }^{15}$.

Op grond van die spanninge en kontradiksies wat onderling in hierdie stel proposisies voorkom, het Diodorus wesenlik die oogmerk om op logiese gronde te argumenteer dat slegs die werklikheid moontlik is. Slegs die geaktualiseerde het potensiaal. Aktualiteit verbrand potensialiteit, as't ware (Sutula 1976:323-330).

Abelardus, in sy antwoord op die vraag wat voor die aanvang van die kruistogte vanuit die veronderstelde heilsgeskiedenis verantwoord moet word - Wat kan God (nie) doen (nie)? - gebruik dan baie eeue later 'n logiese en sistematiese tegniek wat hierdie intense Megariaanse verhouding tussen aktualiteit en potensialiteit oproep. Ons vind by Abelardus 'n subtiele, hoewel duidelike argumentatiewe aansluiting by die dialektiese determiniteitsleer van die antieke Megariërs. Die onderstaande bespreking, gebaseer op die primêre teks van Theologia 'Scholarium' in die Turnholt-uitgawe van Buytaert en Mews ${ }^{16}$ (Abelardus 1987), maak hierdie subtiele filosofies-teologiese terugkoppeling duidelik.

\section{'God kan net doen wat God wel doen' - Theologia 'Scholarium', Opera Theologica III, 511-524}

Tipies van die fusie tussen teologiese posisionering en filosofiese vraagstelling in die Middeleeuse filosofie, begin Abelardus (1987:511) sy eksposisie oor die verhouding tussen aktualiteit en potensialiteit deur te vra: Kan God meer doen of beter doen as wat God tans doen? Meer nog: Kon God in die verlede tyd die dinge wat God tans doen nagelaat het om te doen, sodat God die dinge inderwaarheid nooit sou gedoen het nie en dus tans nie doen nie?

Of ons nou aanvanklik sou toegee dat God dit kan doen, of nie kan doen nie, roep allerlei bykomende vrae op:

\footnotetext{
15. Moet dit dus so verstaan word dat I en II as begronding vir die argument gebruik is en IV as die ontknopende teenstelling van III? Prior ([1955:205-213, 1958:236]; kyk Bobzien [2004:5]) het die argument op meesterlike wyse gerekonstrueer, me inbegrip van die eise wat sowel Stoïsynse redevoering as gewoon modale logika aan so 'n rekonstruksie sou stel. Prior se rekonstruksie is ook ' $n$ rekonstruksie van die orde van die argument. Daarom begin hy by Diodorus se IV:

IV. Indien 'n proposisie nie waar is of noodsaaklik nie waar sal wees nie, is dit onmoontlik.

I. Elke waar proposisie wat korrespondeer met ' $n$ toestand of gebeure in die verlede tyd, is noodsaaklik waar.

II. ' $n$ Onmoontlike proposisie kan nie vanuit ' $n$ moontlike proposisie voortkom nie.

III. lets is slegs moontlik wanneer dit nie waar is of nooodsaaklik waar sal wees
nil

Laat ons hierdie meesterargument verder vereenvoudig

I. Elke verlede waarheid moet noodsaaklik wees.

II. 'n Onmoontlikheid volg nie op 'n moontlikheid nie.

III. ' $n$ Moontlikheid is nie waar nie en sal nie waar wees nie.

IV. Niks is moontlik wat nie waar is of noodsaaklik waar sal wees nie.

Vir Diodorus is dit duidelik dat ' $n$ toekomstige gebeure wat nie gaan gebeur nie, ook in die verlede tyd nie gaan gebeur (sou gebeur het) nie - dit is ' $n$ onmoontlikheid. Omdat ' $n$ moontlikheid nie volg op ' $n$ onmoontlikheid nie, sal dit ook in die toekoms 'n onmoontlikheid wees.

16.Die vrye vertaling en resumerende weergawe van die primêre teks in die onderhawige bespreking is die outeur se eie. Die betroubare Engelse vertaling onderhawige bespreking is die outeur se ele. Die betroubare Engelse vertaling 'Scholarium' stilisties 'n is tis ormuleringspresisie eie aan die styl wat later in die middel- of hoë skolastiek kenmerkend sou word.
}

Indien ons sou postuleer dat God meer kan doen as of beter kan doen as of nalaat om te doen wat God tans doen, is dit duidelik dat die goedheid van God gereduseer sal word ...

(Abelardus 1987:512) $^{17}$

Maar dan moet ook aanvaar word dat God kan nalaat om sekere dinge te doen in die sin dat dit nie dinge is wat God doen nie - dit sal die dinge wees wat paslik vir God sal wees om na te laat of wat goed vir God is om na te laat. Tog kan dit nie goed wees vir God om dieselfde ding te doen en terselfdertyd nie te doen nie (of na te laat om te doen). Dit kan nie goed wees nie omdat niks terselfdertyd gedoen en nie gedoen kan word nie.

Wat God doen, kan God nie terselfdertyd nalaat om te doen nie, aangesien die enigste teenoorgestelde van goed kwaad is. Daar kan geen geldige rede wees waarom God sou wil dat dieselfde ding terselfdertyd gedoen en nie gedoen sal word nie. Wanneer dit dus goed is vir God om iets te doen, is dit nie goed vir God om na te laat om dit te doen nie. God doen of laat na om te doen slegs wat goed is vir God om te doen of na te laat om te doen. Dit word dan duidelik dat God slegs kan doen of kan nalaat om te doen wat God wel doen of wel nalaat om te doen. Omdat dit goed is dat God nalaat wat God nalaat, is dit nie goed dat God dit doen wat God nalaat om te doen nie: gevolglik kan God dit nie doen nie. Sou dit wees dat God wel nalaat om te doen wat goed is vir God om te doen, of dat God sou onttrek van die goeie dinge wat God behoort te doen, sou dit nie as 'n absurde vyandigheid van God teen God self verstaan moes word nie? Terwyl God nóg absurditeit nóg vyandskap teen God duld?

Dit is duidelik dat daar 'n geldige rede moet wees vir wat God ook al doen of nalaat om te doen en gevolglik doen God slegs of laat God slegs na om te doen die dinge wat God behoort te doen of behoort na te laat om te doen. As dit dan korrek is dat alles wat God doen die dinge is wat God behoort te doen, is dit korrek vir God om te doen wat God wel doen en ongetwyfeld behoort God te doen wat dit ook al is wat God doen. En indien God dit behoort te doen, is dit duidelik dat God, teologies en moreel gesproke, nie kan nalaat om dit doen nie. Sekerlik is alles wat reg is om te doen verkeerd om na te laat om te doen - en sekerlik is dit waar dat wie nalaat om te doen wat redelikheid dikteer om te doen, net so in die ongelyk met die waarheid verkeer as iemand wat die onredelike doen. Kan God wat onredelikheid nie duld nie, onredelik wees?

Maar gestel iemand beweer dat op grond van die almag van God wat op geen wyse beperk mag word nie, dat net soos wat God op enige gegewe stadium die regte, goeie en redelike ding doen, dit ewe reg, goed of redelik kon wees indien God iets anders doen en dus nalaat om te doen wat God in werklikheid doen? Daarby: wanneer God gekies het om die een ding te doen, sou die ding wat God nagelaat het om te doen ter wille van die ding wat God wel doen,

17.Abelardus onderskryf en aanvaar dus premissegewys die ononderhandelbare Middeleeuse uitgangspunt dat God redelik is, slegs goed kan doen en dat God die goeie slegs goed kan doen, op ' $n$ wyse dus doen wat God se aanvaarde attribute van redelikheid, vryheid en goedheid kan komplementeer. 
net so reg, goed en redelik gewees het as die ding wat God inderdaad doen? Wat sou die rede wees dat God wel kies om die een ding te doen en nie die ander nie? Die rede is dat daar geen rede is vir God om beide te doen nie. Wat God wel uiteindelik doen, is altyd net so goed as wat God nie doen nie. Watter een God ook al kies om te doen, sou gedoen moet word met reg, goedheid en redelikheid.

Hierdie soort argumentvoering vooronderstel egter dat dit wat nie gedoen is nie, net so noodsaaklik is om gedoen te word as dit wat wel gedoen is en dat dit wat nie gedoen is nie net so goed sou wees indien dit gedoen sou word as dit wat wel gedoen is. Wanneer dit goed is dat iets gedoen word en daar bestaan ' $n$ redelike rede waarom dit gedoen behoort te word, is dit duidelik dat iemand wat nalaat om dit te doen, bewus daarvan dat dit gedoen behoort te word, onredelik optree. Weer: kan God wat onredelikheid nie duld nie, onredelik wees? Gestel egter die bewering word gemaak dat dit wat nie gedoen is nie, slegs goed sou wees indien dit wat wel gedoen is nagelaat is om te doen, is dit sekerlik waar dat presies dieselfde argument sou moes geld vir dit wat inderwaarheid gedoen is. En dit sal beteken God het uiteindelik gedoen wat nie goed was om te doen nie: en dit is ondenkbaar. Dit behoort duidelik te wees: As slegs dit wat God doen, goed vir God is om te doen, is dit wat goed is vir God om te doen, slegs wat God kan doen.

Dit wil volgens Abelardus dan voorkom dat aanvaar moet word, op grond van bogenoemde argument, dat wat moontlik is vir God om te doen, is wat God wel doen. God kan net doen wat God wel doen en God kan slegs nalaat om te doen wat God wel nalaat om te doen, omdat daar in enige geval van God se doen of late om te doen 'n geldige rede is vir die doen of die late. God, as die spitspunt van redelikheid, kan nie enige iets wil of doen wat teen die aanspraak van redelikheid ingaan nie. Eintlik kan niemand redelikerwys iets wil of doen wat nie redelik is nie. God kan logies-aktueel net doen wat God wel doen.

Dit is duidelik dat Abelardus met hierdie argument besig is om potensialiteit aan aktualiteit te subordineer. Maar dan is dit ook duidelik dat Abelardus ernstige teenstand vir hierdie 'Megariaanse' argument verwag: daarom voer hy sy argument verder met verwysing na die hoogs problematiese kwessie in die Middeleeuse diskoers rondom die voorsienigheid van God (Abelardus 1987:515ev). Die veroordeelde mens wat voor God skuldig staan, kan gered word, maar net deur God self. Die deugdelike mens wat minder skuldig voor God staan, kon selfs meer deugdelik wees, maar net as God dit wou. Die veroordeelde mens kan sonder God nie gered word nie en kan self niks doen om gered te word nie - en kan daarom nie geblameer word omdat hy of sy nie die dinge gedoen het wat hy of sy nie kon doen om gered te word nie. God het hierdie veroordeelde mens duidelik nie gebind aan of begaaf met die dinge waardeur hy of sy gered sou kon word nie, omdat dit duidelik is dat hy of sy nie in staat is om homself of haarself te red nie. Hy of sy kan net gered word. Sou dit dan nie redelik van God wees om hom of haar wel te red nie? Is daar 'n verskil tussen 'God red' en om 'deur God gered te word'? As dit moontlik is vir hom of haar om deur God gered te word, hoe kan dit dan onmoontlik wees dat God hom of haar red? Indien die oorsaak moontlik is, moet die gevolg ook moontlik wees, aangesien die 'onmoontlike op geen geldige wyse vanaf die moontlike kan ontwikkel nie' (Abelardus 1987:516).

Abelardus (1987:517) herhaal dan sy vorige gevolgtrekking: Omdat God slegs doen wat God behoort te doen (wat paslik vir God is om te doen) en slegs nalaat om te doen wat God behoort na te laat om te doen (wat paslik vir God is om na te laat om te doen), is dit duidelik dat God slegs kan doen wat God wel doen. Abelardus (1987:517) aanvaar dat dit 'n 'ongewilde gevolgtrekking' is, in stryd met 'wat die heiliges tot dusver hieroor te sê gehad het'. Abelardus (1987:518) reken dat die rede vir die veronderstelde ongewildheid van sy gevolgtrekking enersyds te make het met die feit dat dit 'nou eers weer' gehoor word, tesame met die hoogs antisipeerbare beswaar dat indien selfs mense kan doen wat hulle (normaalweg of andersins) nie doen nie of kan nalaat om dinge te doen wat hulle (normaalweg of andersins) sou doen, die gevolgtrekking duidelik inbreuk maak op die majesteit en eksellensie van God.

Twee opmerkings is hiervanuit belangrik: Die eerste is dat Abelardus daarop sinspeel dat sy argument oud is, maar vir lank nie gehoor is nie. Hy kan daarmee nie Aristoteles se kousaliteitsleer in gedagte hê nie, omdat hy nie toegang tot Aristoteles se kousaliteitsleer gehad het nie. Hy kan hiermee net een ander vergange kousaliteitsleer impliseer: die Meesterargument van Diodorus Cronus, waarop hy in bogenoemde argument aanvanklik subtiel en later woordeliks teruggaan. Tweedens is dit duidelik dat Abelardus, as 'n nominalistiese dialektikus, verseg om van God as 'n algemene kategorie of universaliteit te praat: waar die begrip 'mense' wel nog ' $n$ universaliserende strekking mag hê (minstens in die sin dat daar meer as een mens is en dat uiteenlopende mense soms dieselfde dinge doen), moet enige poging om God te universaliseer, dadelik met ' $n$ partikularisering (wat 'God kan net doen wat God wel doen' inderdaad is) onderbreek word. Waar die begrip 'mense' nog betekenis mag dra in universele sin, is die woord 'God' betekenisloos die oomblik wat dit universaliseer word om iets algemeens aan te dui:

Ons doen dinge wat God nie kan doen nie: ons eet, drink, loop rond en sondig - juis die dinge wat volledig van God se goddelikheid verwyderd staan en vreemd staan teenoor God se eiesoortige dignitas.

(Abelardus 1987:518)

Dit hoort nie by die spesifisiteit van God om die dinge te doen of na te laat om te doen wat mense doen of nalaat om te doen nie. Vanuit hierdie partikulariteitsgerigtheid in sy Godsbeskouing is dit vir Abelardus dus teologies heeltemal onproblematies om te stel dat waar God slegs kan doen wat God doen, mense kan doen wat hulle (normaalweg) nie doen nie. Dit ontkragtig God nie: inteendeel. Abelardus brei in drie opvolgende paragrawe uit waarom hierdie argument syns 
insiens die basis vir 'n post-Augustiniaanse sondebegrip behoort te vorm: Dit is juis omdat mense doen wat hulle nie kan doen nie, of behoort te doen nie, dat die mensheid so reddeloos en skerp afgegrensd teenoor die glorie en majesteit van God staan (Abelardus 1987:519). God daarenteen, kan net doen wat God wel doen. God se handelinge sou daarom volgens sowel Abelardus as Diodorus as streng gedetermineerd en self weer determinerend verstaan moes word. Met voorkennis van die vroeg-skolastiese oorspronge van Abelardus se teks, sou hierdie ekserp vanuit 'Scholarium' net sowel gelees kon word as 'n teologiese eksponering van die Diodoriaanse Meesterargument, waarin Abelardus met sy tematiese terugkoppeling na die Megariërs die klassieke kousaliteitsvraag vanuit 'n aweregse hoek benader en 'n unieke Middeleeuse (hoewel dan 'voorAristoteliese') hermeneutiek van suspisie oproep (kyk ook Sweeney 2006:120-126). Abelardus laat sy post-Carolingiese tydgenote, binne die konteks van die eerste kruistogte wat 'n aanvang neem, so weer oor die vraag 'wat kan God doen?' nadink. Hy gebruik die klassieke verhoudingsvraag na aktualiteit en potensialiteit om hierdie vraag te beantwoord: As God net kan doen wat God wel doen, moet ons beskeie wees oor wat God sal doen. God sal doen wat God wel doen.

Daar is bostaandeaangetoon dat Abelardus in 'Scholarium' met die fragmentariese Megariese erfenis alleen 'n Aristoteliese stemming in die jong, opkomende skoolfilosofieë van die 12de eeu kon skep. Dit getuig van sowel die kreatiewe skerpsinnigheid van sy rehabiliterende bydrae vanuit die antieke filosofiese diskoers van die Megariërs, as wat dit meewerk tot ' $n$ instemmende onderskrywing van Abelardus se eminensie in die post-Carolingiese filosofie, met noster Aristoteles inderdaad ' $\mathrm{n}$ gepaste bynaam vir iemand wat grootliks sonder Aristoteles soos Aristoteles gedink en gepraat het (kyk Clanchy 1999:96). Dit getuig egter ook daarvan dat dit moontlik is om betekenisvolle impulse op 'n intuïtiewe en kreatiewe wyse terug te bring uit die verlede, veral wanneer dit wat 'n mens wel in die hand het, gebroke en pynlik gefragmenteerd is.

\section{Literatuurverwysings}

Abelardus, P., 1987, 'Theologia "Scholarium". Opera Theologica III', in E.M. Buytaert \& C.J. Mews (eds.), Corpus Christianorum, Continuatio Mediaevalis XIII, pp. 511-524, Typographi Brepols Editores Pontificii, Turnholt.

Alexander van Afrodisië, 1899, Commentary on Aristotle's 'Prior Analytics', ed. M Wallies, CAG 4.6, Greimer, Berlyn.

Aristoteles, 1984, The Complete works of Aristotle. Revised Oxford translation, ed J. Barnes, transl. W.D. Ross, Princeton University Press, Princeton, New Jersey.

Armstrong, A.H. (ed.), 1967, The Cambridge history of later Greek and early Medieva philosophy, Cambridge University Press, Londen.

Beukes, J., 2005, 'Terreur, roes en ordes: Die monnik as blywende simbool van erns in die filosofie', HTS Teologiese Studies/Theological Studies 61, 1101-1129.

Beukes, J., 2009a, 'Hamartia: Foucault \& Iran 1978-1979 (I Introduction \& Texts)', HTS Teologiese Studies/Theological Studies 65(1), Art. \#124. doi: 10.4102/hts. v65i1.124.

Beukes, J., 2009b, 'Hamartia: Foucault \& Iran 1978-1979 (II Scholarship \& Significance)', HTS Teologiese Studies/Theological Studies 65(1), Art. \#125. doi: 10.4102/hts.v65i1.125.

Bobzien, S., 1993, 'Chrysippus' modal logic and its relation to Philo and Diodorus', in K. Döring \& T. Ebert (eds.), Dialektiker und Stoiker, pp. 124-147, Franz Steiner, Stuttgart.

Bobzien, S., 1998, Determinism and freedom in Stoic philosophy, Clarendon Press, Oxford.
Dialectical School', Stanford Encyclopedia of Philosophy, viewed February 2008-May 2010, from http://plato.stanford.edu/entries/dialectical-school

Bosley, R.N. \& Tweedale, M. (eds.), 2004, Basic issues in medieval philosophy. Selected readings presenting the interactive discourses among the major figures, Broadview Press, Ontario.

Brower, J. \& Guilfoy, K. (eds.), 2004, The Cambridge companion to Abelard, Cambridge University Press, New York.

Clanchy, M.T., 1999, Abelard: A Medieval life, Wiley-Blackwell, London.

Colish, M.L., 1968, The mirror of language. A study in the medieval theory of knowledge, Yale University Press, New Haven.

Copleston, F.C., 1972, A history of Medieval philosophy, Methuen, London.

Craig, W.L., 1980, The cosmological argument from Plato to Leibniz, MacMillan, Londen.

Dahmen, R., 1906, Darstellung der Abälardischen Ethik, Münster Verlag, Münster.

Denyer, N., 1981, 'Time and modality in Diodorus Cronus', Theoria 47, 31-53. doi: 10.1111/j.1755-2567.1981.tb01236.x

Dronke, P. (ed.), 1988, A history of twelfth-century Western, Cambridge University Press, Cambridge, UK.

Gilson, E., 1955, History of Christian philosophy in the Middle Ages, Random House, New York.

Gracia, J.J.E., 1984, Introduction to the problem of individuation in the early Middle Ages, Catholic University of America Press, Washington.

Haren, M., 1992, Medieval thought. The Western intellectual tradition from antiquity to the thirteenth century, University of Toronto Press, Toronto.

Heidegger, M., 1958, Introduction to metaphysics, transl. R. Mannheim, Yale University Press, New Haven.

Hyman, A., 1973, Philosophy in the Middle Ages: The Christian, Islamic and Jewish traditions, Hackett, Indianapolis.

King, P., 2004, 'Peter Abelard', Stanford Encyclopedia of Philosophy, viewed February 2008-May 2010, from http://plato.stanford.edu/entries/abelard

Klibansky, R., 1982, The continuity of the Platonic tradition during the Middle Ages, Kraus, New York.

Kretzmann, N., Kenny, A \& Pinborg, J., 1982, The Cambridge history of later Medieval philosophy, Cambridge University Press, Cambridge, UK. doi: 10.1017/ CHOL9780521226059

Leff, G., 1958, Medieval thought. St Augustine to Ockham, Penguin, Harmondsworth.

Lewis, N., 1987, 'Determinate truth in Abelard', Vivarium 25, 81-109. doi: 10.1163/156853487X00076

Luscombe, D.E., 1969, The School of Peter Abelard. The influence of Abelard's thought in the early scholastic, Cambridge University Press, Cambridge.

Luscombe, D.E., 1971, (Abelard's) Ethics, Oxford University Press, Oxford.

Luscombe, D.E., 1992, 'The School of Peter Abelard revisited', Vivarium 30, 127-138. doi: $10.1163 / 156853492 \times 00098$

Marenbon, J., 1988, Early Medieval philosophy (488-1150). An introduction, Routledge, New York.

Marenbon, J., 1999, The philosophy of Peter Abelard, Cambridge University Press, Cambridge, UK.

Mates, B., 1949, 'Diodorean implication', Philosophical Review 58, 234-242. doi: $10.2307 / 2181853$

McCabe, J., 1972 [1901], Peter Abelard. Burt Franklin Research and Source Works Series: Philosophy \& Religious History Monographs 110, Lenox Hill, New York.

Mews, C.J., 1986, 'On dating the works of Peter Abelard', Archives d'Histoire Doctrinale et Littéraire du Moyen Age 60, 73-134.

Mews, C.J. \& Jolivet, J., 1990, 'Peter Abelard and his influence', in G. Floistad (ed.), Contemporary Philosophy 6/1: Philosophy and Science in the Middle Ages, pp. 105-140, Kluwer, Amsterdam.

Mews, C.J., 2001, Abelard and his legacy, Ashgate, Aldershot.

Murray, A.V., 1967, Abelard and St Bernard: A study in twelfth-century 'modernism', Barnes \& Noble, New York.

Price, B.B., 1992, Medieval thought. An introduction, Blackwell, Oxford.

Prior, A.N., 1955, 'Diodorean modalities', Philosophical Quarterly 5, 205-213. doi: $10.2307 / 2957434$

Prior, A.N., 1958, 'Diodorus and modal logic - A correction', Philosophical Quarterly 8 , 226-230. doi: 10.2307/2216984

Sedley, D., 1977, 'Diodorus Cronus and Hellenistic philosophy'Proceedings of the Cambridge Philological Society 23, 74-120.

Spade, P.V., 1995, Five texts on the medieval problem of universals, Hackett, Indianapolis.

Sutula, J., 1976, 'Diodorus and the Master Argument', Southern Journal of Philosophy 14, 323-344. doi: 10.1111/j.2041-6962.1976.tb01290.x

Sweeney, E.C., 2006, 'Abelard: a twelth-century hermeneutics of suspicion', in Logic, theology, and poetry in Boethius, Abelard, and Alan of Lille: Words in the absence of things, pp. 63-126, Palgrave Macmillan, New York.

Tweedale, M., 1976, Abailard on universals, North-Holland, Amsterdam. 
Tweedale, M., 1982, 'Abelard and the culmination of the old logic', in N. Kretzmann, A. Kenny \& J. Pinborg (eds.), The Cambridge history of Later Medieval philosophy. From the rediscovery of Aristotle to the disintegration of Scholas
1600, pp. 143-157, Cambridge University Press, Cambridge, UK.

Tweedale, M. (transl.), 2004, 'Excerpts from Theologia 'Scholarium”, in R.N. Bosley \& M. Tweedal (eds.), Basic issues in Medieval philosophy. Selected readings presenting the interactive discourses among the major figures, pp. 19-23, Broadview Press, Ontario.

Wadell, H., 2008, Peter Abelard, Buck Press, Bubuashie.

Weidemann, H., 1987, 'Das sogenannte Meisterargument des Diodoros Kronos und der Aristotelische Möglichkeitsbegriff', Archiv für Geschichte der Philosophie 69, 18-53. doi: 10.1515/agph.1987.69.1.18
Weidemann, H., 2008, 'Aristotle, the Megarics, and Diodorus Cronus on the notion of possibility'American Philosophical Quarterly 45, 131-148.

Weinberg, J.R., 1964, A short history of Medieval philosophy, Princeton University Press, Princeton.

Weingart, R.E., 1970, The logic of divine love: The soteriology of Peter Abailard, Oxford University Press, Oxford.

Wilks, I., 2008, 'Peter Abelard and his contemporaries', in D. Gabbay \& J. Woods (eds.), Medieaval and Renaissance Logic, pp. 83-156, Elsevier, Amsterdam. doi 10.1016/S1874-5857(08)80024-6 